\title{
Qualitative and quantitative differences between taste buds of the rat and mouse
}

\author{
Huazhi Ma1,2,3, Ruibiao Yang1,2, Stacey M Thomas ${ }^{1,2}$ and \\ John C Kinnamon*1,2
}

\author{
Address: ${ }^{1}$ Department of Biological Sciences, University of Denver, Denver, Colorado 80210, USA, ${ }^{2}$ Rocky Mountain Taste and Smell Center, \\ Aurora, Colorado 80045, USA and ${ }^{3}$ Beijing Institute of Pharmacology and Toxicology, Beijing 100850, China \\ Email: Huazhi Ma - hzma62@hotmail.com; Ruibiao Yang - ryang@du.edu; Stacey M Thomas - stathoma@du.edu; \\ John C Kinnamon* - jkinnamo@du.edu \\ * Corresponding author
}

Published: 05 January 2007

BMC Neuroscience 2007, 8:5 doi:10.1 186/147/-2202-8-5

This article is available from: http://www.biomedcentral.com/I47I-2202/8/5

(c) 2007 Ma et al; licensee BioMed Central Ltd.

This is an Open Access article distributed under the terms of the Creative Commons Attribution License (http://creativecommons.org/licenses/by/2.0), which permits unrestricted use, distribution, and reproduction in any medium, provided the original work is properly cited.
Received: 3I July 2006

Accepted: 05 January 2007

\begin{abstract}
Background: Numerous electrophysiological, ultrastructural, and immunocytochemical studies on rodent taste buds have been carried out on rat taste buds. In recent years, however, the mouse has become the species of choice for molecular and other studies on sensory transduction in taste buds. Do rat and mouse taste buds have the same cell types, sensory transduction markers and synaptic proteins? In the present study we have used antisera directed against PLC $\beta 2$, $\alpha$-gustducin, serotonin (5-HT), PGP 9.5 and synaptobrevin-2 to determine the percentages of taste cells expressing these markers in taste buds in both rodent species. We also determined the numbers of taste cells in the taste buds as well as taste bud volume.
\end{abstract}

Results: There are significant differences $(p<0.05)$ between mouse and rat taste buds in the percentages of taste cells displaying immunoreactivity for all five markers. Rat taste buds display significantly more immunoreactivity than mice for PLC $\beta 2$ (31.8\% vs $19.6 \%$ ), $\alpha$-gustducin (I8\% vs $14.6 \%$ ), and synaptobrevin-2 (3I.2\% vs $26.3 \%)$. Mice, however, have more cells that display immunoreactivity to 5-HT (I5.9\% vs I3.7\%) and PGP 9.5 (I4.3\% vs $9.4 \%$ ). Mouse taste buds contain an average of 85.8 taste cells vs 68.4 taste cells in rat taste buds. The average volume of a mouse taste bud $\left(42,000 \mu \mathrm{m}^{3}\right)$ is smaller than a rat taste bud $\left(64,200 \mu \mathrm{m}^{3}\right)$. The numerical density of taste cells in mouse circumvallate taste buds $\left(2.1\right.$ cells $\left./ 1000 \mu \mathrm{m}^{3}\right)$ is significantly higher than that in the rat ( 1.2 cells $\left./ 1000 \mu \mathrm{m}^{3}\right)$.

Conclusion: These results suggest that rats and mice differ significantly in the percentages of taste cells expressing signaling molecules. We speculate that these observed dissimilarities may reflect differences in their gustatory processing.

\section{Background}

Mammalian taste buds are onion-shaped structures specialized for the detection of aqueous stimuli. Based on morphological criteria, rodent taste cells have been classi- fied into types I, II, III, peripheral and basal cells [1-12]. Type I cells in rodents are slender and possess an electrondense cytoplasm and several long, apical microvilli extending into the oral cavity. A distinguishing feature of 
a type I cell is the presence of many 100-400 nm dense granules in the apical cytoplasm. Type II cells are characterized by the presence of an electron-lucent cytoplasm and large circular or ovoid nuclei. Type II cells possess several short microvilli of uniform length extending into the taste pore. Type III cells are slender and exhibit morphology and cytoplasmic electron density intermediate between type I and type II cells. The nuclei of type III cells are slender and possess prominent invaginations. Two distinguishing features of type III cells are the single blunt microvillus that extends into the taste pore and the presence of synapses onto nerve processes $[11,13,14]$.

Only recently are the functional differences of the cell types becoming understood. Still, it is not clear which taste cell types are the receptors. Based on the presence of synaptic foci, it was believed that type III cells were the only taste bud receptor cells [15-18]. Evidence that type II cells are associated with transduction molecules, however, suggested a sensory for this cell type. For example, some type II taste cells express the taste signaling molecules $\alpha$ gustducin, PLC $\beta 2$, and the type III IP 3 receptor $\left(\mathrm{IP}_{3} \mathrm{R} 3\right)$ in rat circumvallate taste buds [19-22]. It is significant, however, that type II taste cells apparently lack classical synapses. Likewise, some type III taste cells display immunoreactivity to serotonin (5-HT) in rat and mouse circumvallate taste buds [23], neural cell adhesion molecule (NCAM) [24], and synaptosome-associated protein of $25 \mathrm{kDa}$ (SNAP-25) in rat circumvallate taste buds [13]. Immunoreactivity to ubiquitin carboxyl terminase (protein gene product 9.5, [PGP 9.5]) [11] and the synaptobrevin-2 (vesicle associated membrane protein-2, VAMP2) [14] are both found in type II and III taste cells in rat circumvallate taste buds. A small percentage (3.5\%) of PLC 32 or $\mathrm{IP}_{3} \mathrm{R} 3$ immunoreactive cells also display 5-HTLIR. It is believed that PLC $\beta 2$ or $\mathrm{IP}_{3} \mathrm{R} 3$ is also present in a small subset of type III cells in rat circumvallate taste buds [21]. Quantitation studies have demonstrated that approximately $24 \%$ of the taste cells in rat circumvallate papillae display $\alpha$-gustducin-LIR [25], whereas another study showed that $\alpha$-gustducin is present in 33\% of taste cells in mouse circumvallate papillae [26]. PGP 9.5 is present approximately in $14.6 \%$ of the taste cells in rat circumvallate taste buds [25] and 23\% of taste cells in mouse circumvallate taste buds [26]. Based on these preliminary data, it is likely that there are differences in cell type labeling between rats and mice.

Many of the electrophysiological, ultrastructural, and immunocytochemical studies on rodent taste buds have been carried out on rat taste buds. In recent years, however, the mouse has become the species of choice for molecular and other studies on sensory transduction in taste buds. Do rat and mouse taste buds have the same cell types, sensory transduction markers and synaptic pro- teins? Recent research indicates that there are differences in electrophysiological properties, expression of markers and innervation between rat and mouse taste buds [2730]. The acid-sensing ion channel-2 (ASIC-2) is widely believed to be a receptor for acid taste in rat taste cells, however, ASIC-2 is not expressed in mouse taste cells and ASIC-2 knock-out mice exhibited normal physiological responses to acid taste stimuli [28]. ASIC-2 is an acid taste receptor in rat taste cells, but not in mouse taste cells. Rat and mouse taste buds are innervated differently by peripheral taste neurons $[29,30]$. Three to five ganglion cells innervate a single bud in mice while there is a more divergent innervation of buds in the rat $[29,30]$

In the present study we have used antisera directed against PLC $\beta 2$, $\alpha$-gustducin, 5-HT, PGP 9.5 and synaptobrevin-2 to determine the percentages of taste cells expressing these markers in circumvallate taste buds of both rodent species. In addition we have determined the numerical density of taste cells and taste bud volume between rat and mouse circumvallate taste buds using serial transverse sections.

\section{Results \\ Serotonin (5-HT)}

Serotonin-LIR is present in a small subset of taste cells in rodent taste buds. The animal is injected with the immediate precursor, 5-HTP, according to the method of Kim and Roper [23]. Previous studies have demonstrated that serotonin is present in a subset of type III taste cells in rat and mouse circumvallate taste buds $[11,23]$. Our results show that a small subset of slender taste cells display serotonin-like immunoreactivity (LIR) in both rat and mouse circumvallate taste buds.

Immunoreactivity is present in both the cytoplasm and nuclei (Fig. 1). A single taste bud profile contains approximately 2.5 taste cells in rat and 2.8 taste cells in mouse displaying serotonin immunoreactivity (Table 1). We examined 141 taste buds from 5 rats and 221 taste buds from 10 mice. A total of 353 immunoreactive cells were found in the rat taste buds and 621 immunoreactive cells in the mouse taste buds were counted. There is a significant difference between rat (13.7\%) and mouse circumvallate taste buds $(15.9 \%)$ in the percentage of taste cells displaying serotonin-LIR ( $\mathrm{p}<0.05)$ (Fig. 2).

\section{PGP 9.5}

Subsets of taste cells and nerve processes in both rat and mouse circumvallate taste buds display PGP 9.5-LIR (Fig. 3). Three subsets of PGP 9.5-LIR nerve processes are present: intragemmal, perigemmal and extragemmal. Intense immunoreactivity is associated with the nerve plexus located at the base of the taste bud. Some PGP 9.5LIR taste cells are slender, spindle-shaped cells with irreg- 

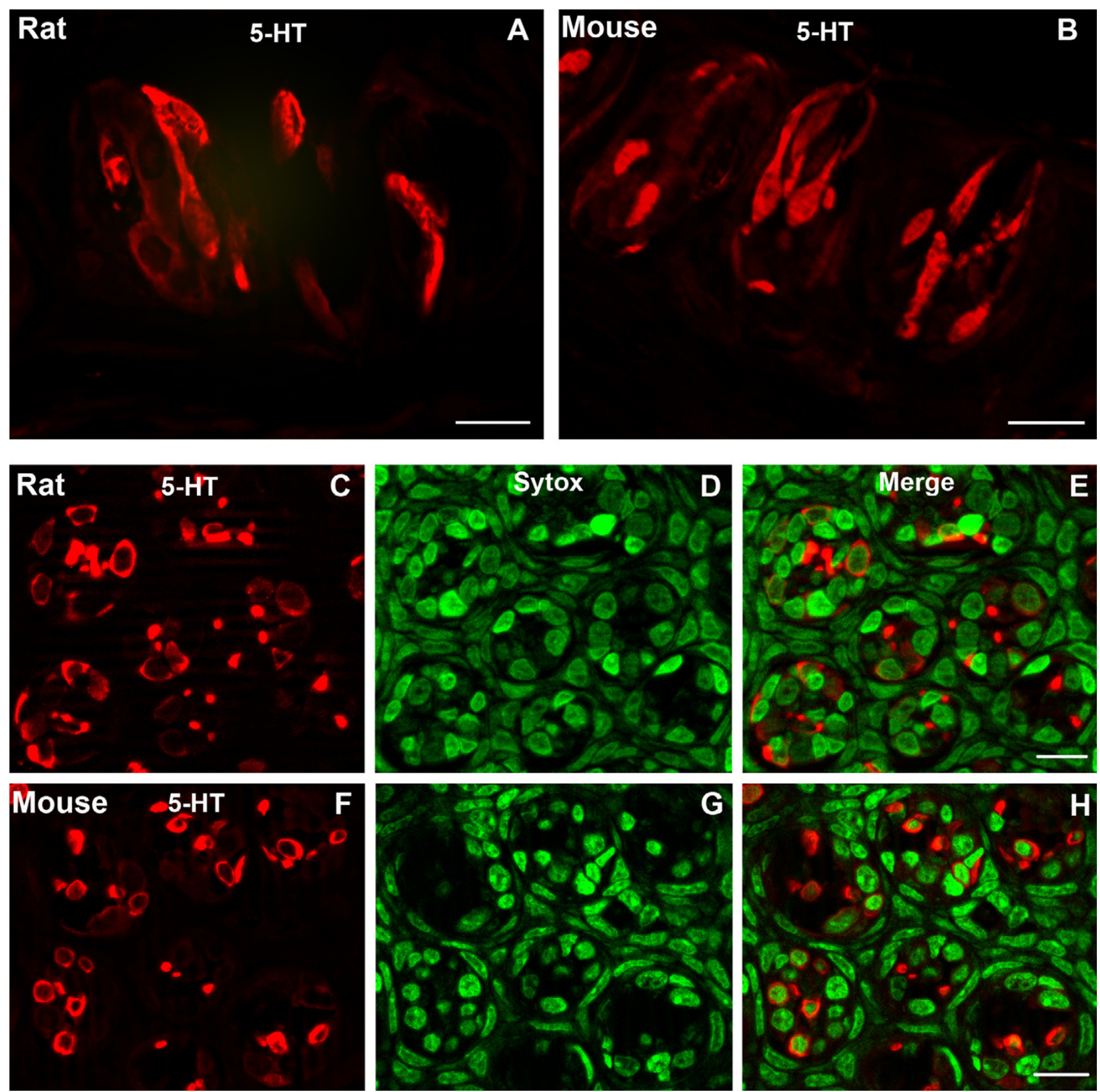

\section{Figure I}

Confocal laser scanning microscopy (CLSM) images of 5-HT-LIR (5-HT) in taste buds of rat and mouse circumvallate papillae. Longitudinal sections show a small subset of taste cells displaying 5-HT-LIR in rat (A) and mouse taste buds (B). Both cytoplasm and nuclei of taste cells display 5-HT-LIR. Transverse sections show 5-HT-LIR in rat (C-E) and mouse taste buds (F-H). The red cells are immunoreactive taste cells ( $C$ and $F$ ). Sytox-stained nuclei are shown in green (D and $G$ ), which stain all cells. Merges of red and green images are shown in $E$ and $H$. Scale bars $=20 \mu \mathrm{m}$.

ular nuclei, while others have large ovoid to round nuclei. Whereas each taste bud profile in the rat contains approximately 1.7 PGP 9.5-LIR taste cells, approximately 3 taste cells per taste bud profile are immunoreactive for PGP 9.5 in the mouse (Table 1). There is a significant difference ( $\mathrm{p}$ $<0.001$ ) in the percentages of PGP 9.5 immunoreactive taste cells between rat and mouse circumvallate taste buds. Approximately $14.3 \%$ of the taste cells in the mouse 


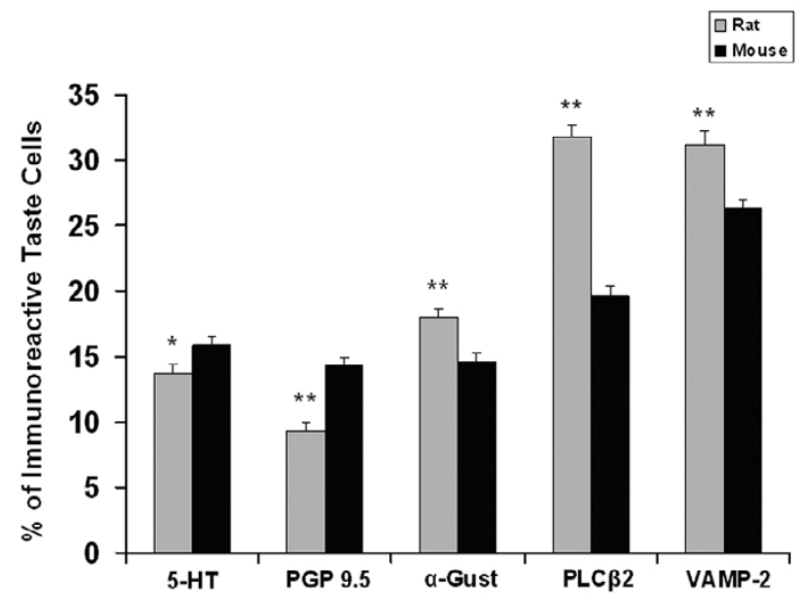

Figure 2

Quantitation of taste cells displaying different immunoreactivity to markers in rat and mouse circumvallate taste buds. Values represent the mean percentages of immunoreactive taste cells \pm SEM. *, $p<0.05$; **, $p<0.0$ I. $\alpha$-Gust, $\alpha$-gustducin; VAMP-2, synaptobrevin-2.

display PGP 9.5-LIR, while only 9.4\% taste cells in the rat exhibit PGP 9.5-LIR (Fig. 2).

\section{$\alpha$-gustducin}

$\alpha$-gustducin is a $\mathrm{G}$ protein believed to be involved in the transduction pathways for bitter and sweet taste [31-34]. $\alpha$-gustducin may also play a role in umami taste $[35,36]$. $\alpha$-gustducin is present in a subset of type II cells [19]. Our results show that a subset of taste cells express $\alpha$-gustducin-LIR in both mouse and rat circumvallate taste buds. The $\alpha$-gustducin-LIR taste cells are spindle-shaped with large, round nuclei. Immunoreactivity is cytoplasmic; no immunoreactivity is associated with the nuclei.

$\alpha$-gustducin immunoreactive cells extend from the basal lamina to the taste pore (Fig. 4). We analyzed 197 taste buds from five rats and 181 taste buds from ten mice. Cells were scored as immunoreactive only if the cellular profile contained a nuclear profile. We observed 635 immunoreactive taste cells in the rat and 482 immunoreactive taste cells in mouse taste buds (Table 1). Approximately $18 \%$ of the taste cells in rat taste buds and $14.6 \%$ of taste cells in mouse taste buds displayed $\alpha$-gustducinLIR. The numbers of $\alpha$-gustducin-LIR immunoreactive taste cells in the rat were significantly different from those in the mouse ( $\mathrm{p}<0.01$ ) (Fig. 2).

\section{PLC $\beta 2$}

Phospholipase C $\beta 2$ (PLC $\beta 2$ ) is thought to be essential for the transduction of bitter, sweet, and umami stimuli [37]. A large subset of taste cells in both rat and mouse circumvallate taste buds display PLC $\beta 2$-LIR. The immunoreactive cells are spindle-shaped with round nuclei resembling type II taste cells (Fig. 5). We counted 935 PLC 32 -LIR cells from 152 rat taste buds and 666 PLC $\beta 2$-LIR cells from 163 mouse taste buds. Whereas $31.8 \%$ of rat circumvallate taste cells display PLC $\beta 2$-LIR, only $19.6 \%$ of the mouse circumvallate taste cells display PLC $\beta 2$-LIR. Thus, rat taste buds contain higher percentages of PLC $\beta 2$-LIR cells than mouse taste buds ( $\mathrm{p}<0.001)$ (Fig. 2).

\section{Synaptobrevin-2}

Synaptobrevin-2 (VAMP-2) is a synaptic vesicle membrane protein that plays an important role in the exocytosis of neurotransmitter release at the synapse [38-40]. Previous studies have shown that synaptobrevin-2-LIR is present subsets of both type II and type III taste cells in rat taste buds [14]. Synaptobrevin-2 is present in a large subset of taste cells and nerve processes in both rat and mouse circumvallate taste buds (Fig. 6). Approximately 35\% of the cells in taste buds from rat circumvallate papillae display synaptobrevin-2-LIR [14]. Most of the immunoreactive taste cells are spindle shaped with circular to ovoid nuclei. A smaller subset of synaptobrevin-2-LIR taste cells possessed cells that are slender in shape. We examined a total 152 taste buds from five rats and 241 taste buds from

Table I: Quantitation of immunoreactive cells in rat and mouse circumvallate taste buds

\begin{tabular}{|c|c|c|c|c|c|c|}
\hline Antibodies & Animals & No. of TBP & No. of TCs & TCs/TBP (Mean \pm SD) & No. of LIR-TCs & LIR-TCs/TBP (Mean \pm SD) \\
\hline \multirow[t]{2}{*}{$5-\mathrm{HT}$} & 5 rats & $14 \mid$ & 2681 & $19.0 \pm 6.5$ & 353 & $2.5 \pm 1.5$ \\
\hline & 10 mice & 221 & 4019 & $18.2 \pm 6.1$ & 621 & $2.8 \pm 1.6$ \\
\hline \multirow{2}{*}{ PGP 9.5} & 5 rats & 144 & 2617 & $18.2 \pm 5.9$ & 240 & $1.7 \pm 1.2$ \\
\hline & 10 mice & 146 & 3449 & $23.6 \pm 6.8$ & 437 & $3.0 \pm 1.5$ \\
\hline \multirow[t]{2}{*}{$\alpha$-gustducin } & 5 rats & 197 & 3757 & $19.1 \pm 6.9$ & 635 & $3.6 \pm 1.5$ \\
\hline & 10 mice & 181 & 3619 & $20.0 \pm 7.0$ & 482 & $2.7 \pm 1.5$ \\
\hline \multirow[t]{2}{*}{ PLC $\beta 2$} & 5 rats & 152 & 2935 & $19.3 \pm 7.3$ & 935 & $6.2 \pm 3.1$ \\
\hline & 10 mice & 163 & 3549 & $21.8 \pm 8.2$ & 666 & $4.1 \pm 2.1$ \\
\hline \multirow[t]{2}{*}{ VAMP-2 } & 5 rats & 151 & 2910 & $19.3 \pm 6.6$ & 870 & $5.8 \pm 2.2$ \\
\hline & 10 mice & 241 & 5063 & $21.0 \pm 7.0$ & 1290 & $5.4 \pm 2.4$ \\
\hline
\end{tabular}

TCs = Taste cell, LIR-TCs = Immunoreactive taste cells, TBP = Taste bud profile. 

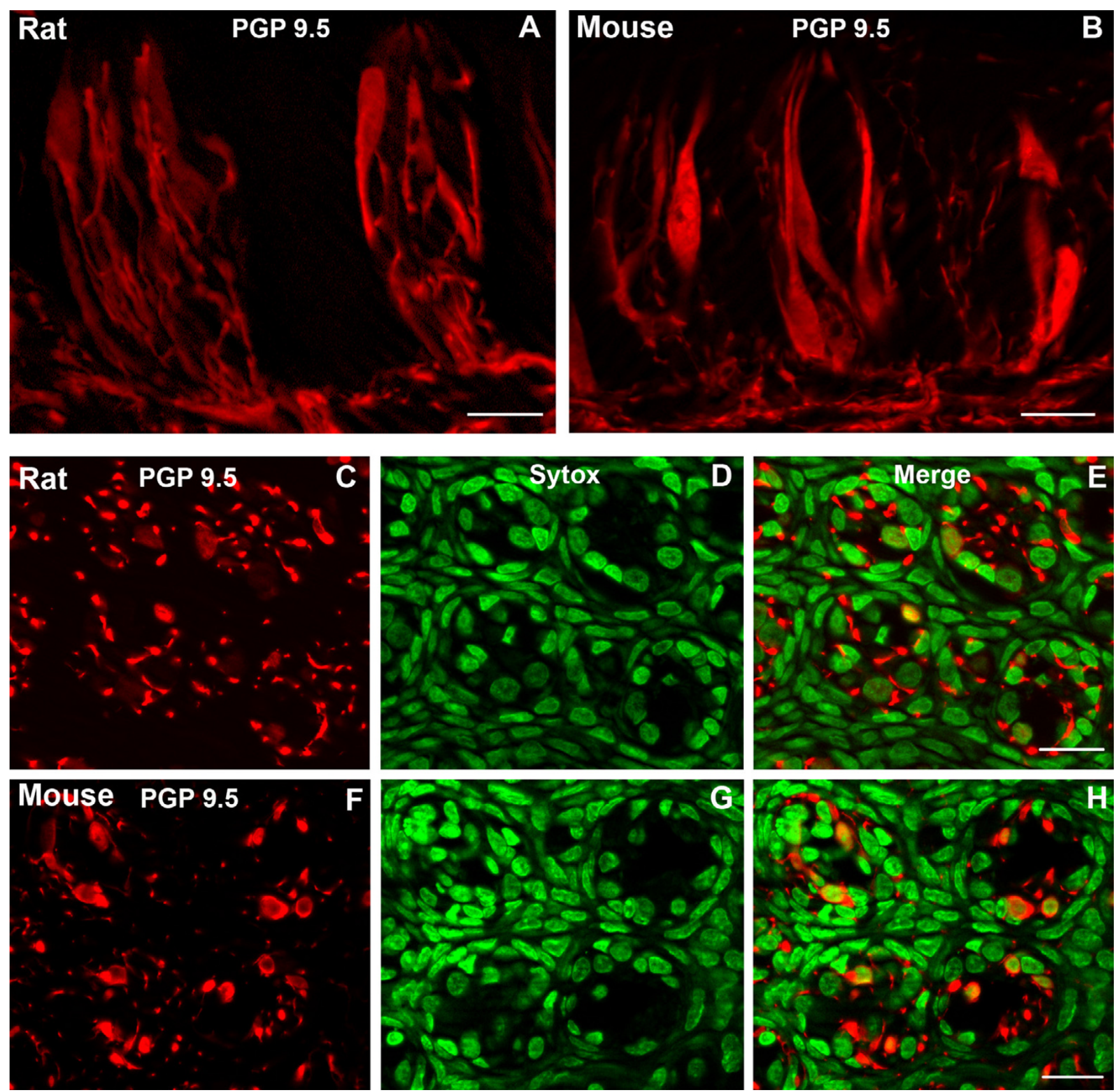

Figure 3

Confocal laser scanning microscopy (CLSM) images of PGP 9.5-LIR (PGP 9.5) in taste buds of rat and mouse circumvallate papillae. Longitudinal sections show a small subset of taste cells and nerve processes expressing PGP 9.5 in rat (A) and mouse taste buds (B). Both cytoplasm and nuclei of taste cells display PGP 9.5-LIR. Transverse sections show PGP 9.5-LIR in rat (C-E) and mouse taste buds $(F-H)$. Immunoreactive taste cells and nerve processes are shown in $C$ and $F$. Sytox-stained nuclei are shown in $D$ and $G$ and merges are shown in $E$ and $H$. Scale bars $=20 \mu \mathrm{m}$. 

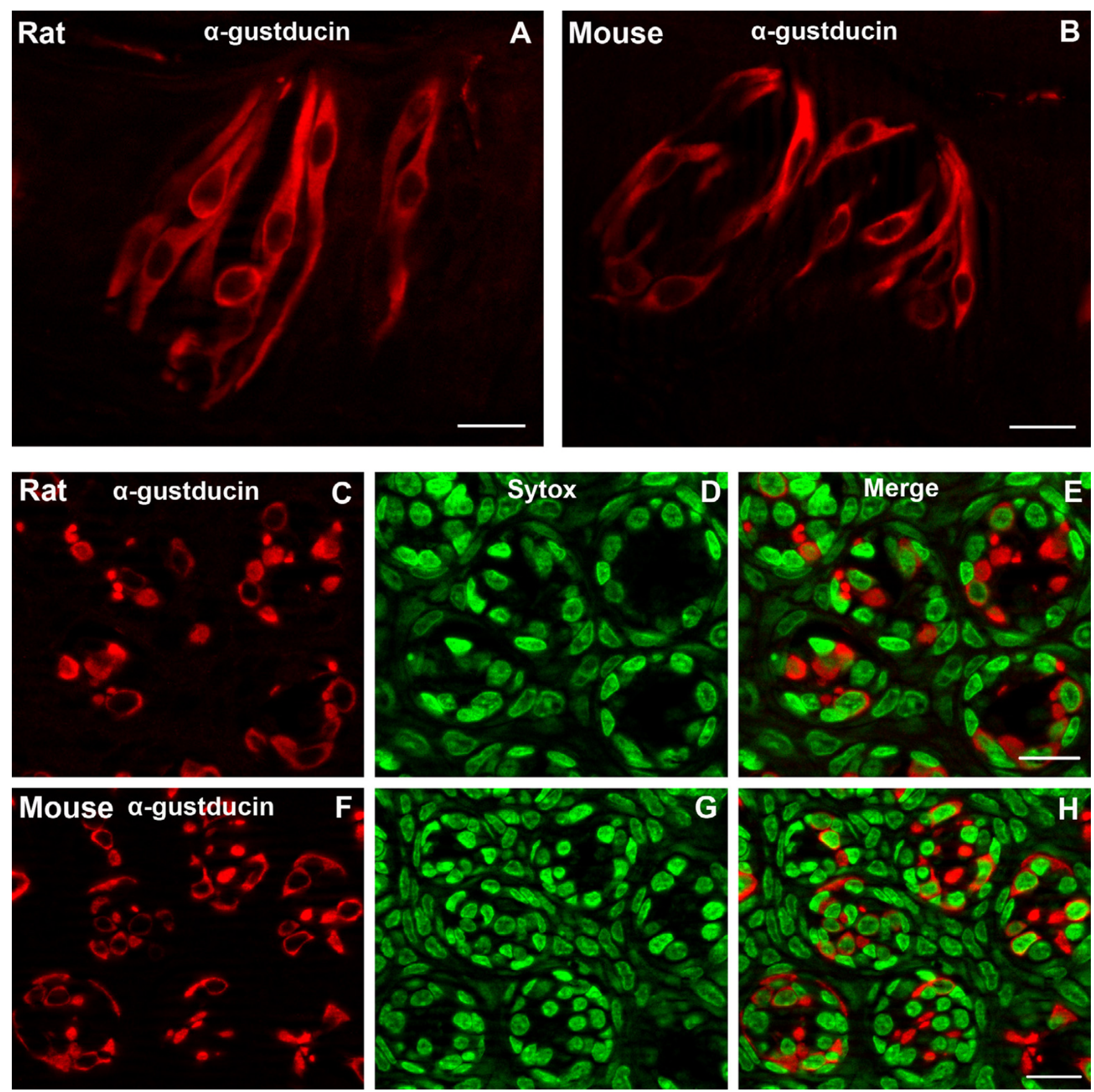

\section{Figure 4}

Confocal laser scanning microscopy (CLSM) images of $\alpha$-gustducin-LIR ( $\alpha$-gustducin) in taste buds of rat and mouse circumvallate papillae. Longitudinal sections show a subset of taste cells displaying $\alpha$-gustducin-LIR in rat (A) and mouse taste buds (B). The $\alpha$-gustducin-LIR taste cells are spindle-shaped with large, round nuclei. Transverse sections show $\alpha$-gustducin-LIR in rat (C-E) and mouse taste buds (F-H). The immunoreactivity is only cytoplasmic in both transverse and longitudinal sections. Immunoreactive taste cells (red) are shown in C and F. Sytox-stained nuclei (green) are shown in D and G and merges are shown in $\mathrm{E}$ and $\mathrm{H}$. Scale bars $=20 \mu \mathrm{m}$.

ten mice. We found 870 taste cells displaying synaptobrevin-2-LIR in rat circumvallate taste buds, and 1290 taste cells displaying synaptobrevin-2-LIR in mouse circumval- late taste buds (Table 1). There is a significantly higher percentage of taste cells displaying immunoreactivity to 

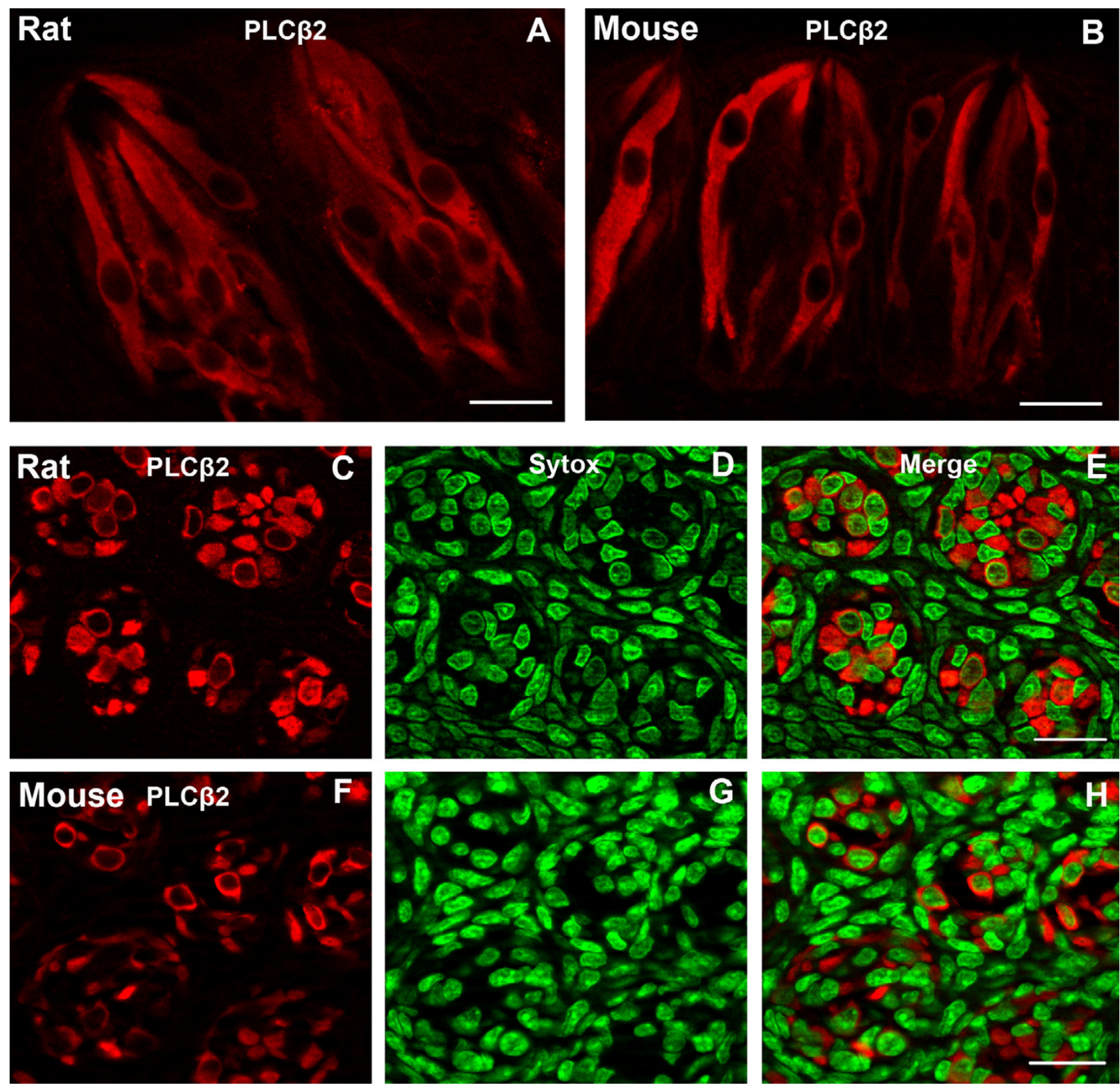

Figure 5

Confocal laser scanning microscopy (CLSM) images of PLC $\beta 2$-LIR (PLC $\beta 2)$ in taste buds of rat or mouse circumvallate papillae. Longitudinal sections show a large subset of taste cells expressing PLC $\beta 2$ in rat $(A)$ and mouse taste buds (B). The PLC $\beta 2$-LIR taste cells are spindle-shaped with large, round nuclei. Transverse sections show PLC 32 -LIR in rat (C-E) and mouse taste buds $(\mathrm{F}-\mathrm{H})$. The immunoreactivity is restricted to the cytoplasm in both transverse and longitudinal sections. Immunoreactive taste cells (red) are shown in C and F. Sytox-stained nuclei (green) are shown in D and G and merges are shown in E and H. Scale bars $=20 \mu \mathrm{m}$.

synaptobrevin-2 in rat circumvallate taste buds versus mouse taste buds (31.2\% vs 26.3\%) (Fig. 2).

\section{Numerical density of taste cells}

Forty-one taste buds from 3 mice and 42 taste buds from 3 rats were analyzed (Table 2 ). Mouse taste buds contain 

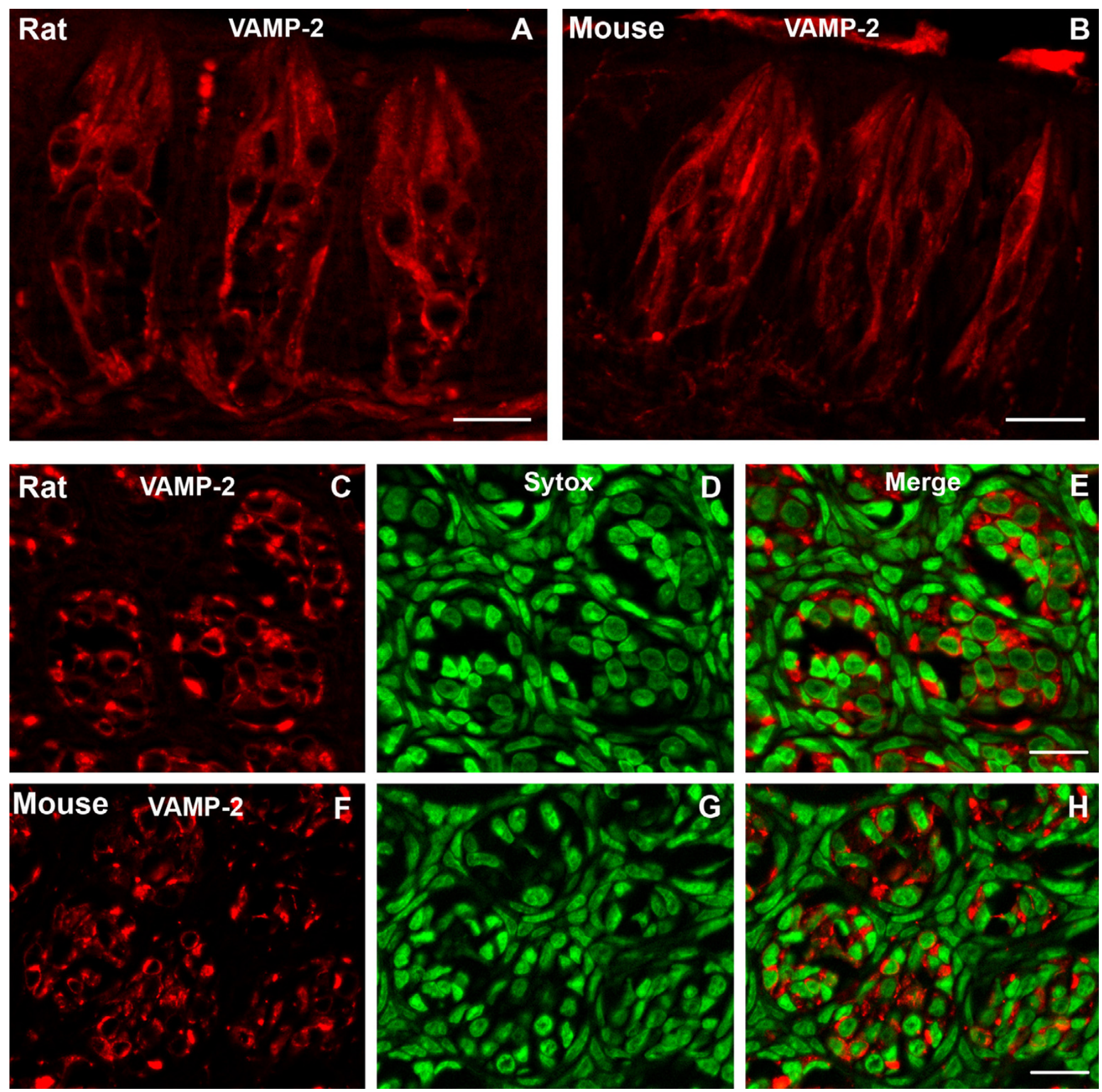

\section{Figure 6}

Confocal laser scanning microscopy (CLSM) images of synaptobrevin-2-LIR (VAMP-2) in taste buds of rat or mouse circumvallate papillae. Longitudinal sections show a large subset of taste cells and nerve processes displaying synaptobrevin-2-LIR in rat (A) and mouse taste buds (B). Transverse sections show synaptobrevin-2-LIR in rat (C-E) and mouse taste buds (F-H). The red are immunoreactive taste cells and nerve processes ( $C$ and $F$ ). Immunoreactivity is restricted to the cytoplasm (red) in both transverse and longitudinal sections. Sytox-stained nuclei (green) are shown in D and G and merges are shown in $E$ and $H$. Scale bars $=20 \mu \mathrm{m}$.

an average of 85.8 taste cells (Mean \pm SD: $85.8 \pm 33.9$ ) vs 68.4 taste cells (Mean \pm SD: $68.4 \pm 20.7$ ) in rat taste buds. The numbers of cells per taste bud ranged from 32 to 152 in the mouse and 34 to 126 in the rat. Although the average mouse taste bud contains more taste cells than a rat taste bud, the average volume of a mouse taste bud 
$\left(42,000 \mu \mathrm{m}^{3}\right)$ is smaller than a rat taste bud $(64,200$ $\left.\mu \mathrm{m}^{3}\right)$. The numerical density of taste cells in mouse circumvallate taste buds $\left(2.1\right.$ cells $\left./ 1000 \mu \mathrm{m}^{3}\right)$ is significantly higher than that in the rat $\left(1.2\right.$ cells $\left./ 1000 \mu \mathrm{m}^{3}\right)$ (Table 2$)$.

\section{Discussion}

In the present study we have demonstrated that significant differences exist between rats and mice with regard to the presence of signaling molecules and taste bud cell markers. Using unbiased systematic sampling and immunocytochemistry we have quantified the presence of signaling molecules/taste cell markers including serotonin, PGP 9.5, $\alpha$-gustducin, phospholipase C $\beta 2$ (PLC $\beta 2$ ) and synaptobrevin-2. Our results indicate that there are significant differences $(p<0.05)$ between mouse and rat taste buds in the percentages of taste cells displaying immunoreactivity (IR) for all five markers. Higher percentages of rat taste bud cells exhibit immunoreactivity to $\alpha$-gustducin, PLC $\beta 2$ and synaptobrevin-2 compared with the mouse. Mouse taste buds however, contain higher percentages of taste cells displaying serotonin- and PGP 9.5LIR.

\section{Serotonin}

Serotonin is a putative neurotransmitter or neuromodulator candidate in the taste bud $[41,42]$. Previous studies have suggested that serotonin is present in type III taste cells in rat, rabbit, and mouse taste buds $[23,43,44]$. Yee et al. [11] proposed that the type III cells in rat circumvallate taste buds are two of varieties: those immunoreactive for serotonin and those immunoreactive for PGP 9.5. Taste bud synapses in rat circumvallate taste buds are only associated with the type III cells $[11,13,14]$. Our quantitation results indicate there is a significant difference $(\mathrm{p}<$ 0.05 ) in the percentages of taste cells displaying serotonin-LIR between mouse and rat circumvallate taste buds: $15.9 \%$ of mouse taste cells contain serotonin compared with $13.7 \%$ of rat taste bud cells. Based on previous work from our laboratory, we believe that serotonin-LIR colocalizes with SNAP-25-LIR in taste cells of rat taste buds [45].

\section{PGP 9.5}

PGP (protein gene product) 9.5 is a neuronal marker that has also been found in certain types of paraneurons $[46,47]$. PGP 9.5-LIR has been identified in taste buds of the rat $[48,49]$. Previously we found PGP 9.5-LIR in subsets of both type II and type III cells in circumvallate taste buds of the rat [11]. We also observed synapses onto nerve processes from PGP 9.5-LIR type III taste cells. Whereas one subset of type III cells in the rat accumulate serotonin but do not express PGP 9.5, the remainder of the type III cells express PGP 9.5 but do not accumulate serotonin. Similarly, two subsets of type II cells exist: those immunoreactive for PGP 9.5 and those immunoreactive for $\alpha$-gustducin. Our results indicate that $14.3 \%$ of taste cells express PGP 9.5 in mouse, while 9.4\% display PGP 9.5LIR in rat. Thus, the PGP 9.5-LIR subsets of type II and type III cells may constitute small percentages of those cell types. It would be of benefit for future studies to elucidate the percentages of these subsets of type II and type III cells.

\section{$\alpha$-gustducin and PLC $\beta 2$}

$\alpha$-gustducin and PLC $\beta 2$ are believed to participate in bitter, sweet and umami taste transduction [34-37]. $\alpha$-gustducin knockout mice show markedly reduced behavioral and electrophysiological responses to both bitter and sweet compounds [31]. We have demonstrated that all $\alpha$ gustducin immunoreactive cells and most PLC $\beta 2$-immunoreactive taste cells are type II taste cells. A small percentage $(3.5 \%)$ of PLC 32 -immunoreactive taste cells appear to be type III cells $[19,21]$. Virtually all $\alpha$-gustducin-LIR taste cells display PLC $\beta 2$-LIR, while only a subset of PLC $\beta 2$ immunoreactive taste cells display $\alpha$-gustducin-LIR $[20,22]$. The percentages of $\alpha$-gustducin- and PLC $\beta 2$-LIR taste cells in rat circumvallate taste buds $(18 \%$ and $31.8 \%$ respectively) are higher than those in mouse (14.6\% and $19.6 \%)$.

\section{Synaptobrevin-2}

Synaptobrevin-2 is a vesicle-associated membrane protein. Previous results from our laboratory indicate that synaptobrevin-2 is present in a subset of type II and type III cells. Our data suggest that taste cells with synapses

Table 2: Numerical density of taste cells in rat and mouse circumvallate papillae taste buds

\begin{tabular}{|c|c|c|c|c|}
\hline Animals & No. of TB & Cell No./TB (Mean \pm SD) & TB Volume $\left(\times 1000 \mu \mathrm{m}^{3}\right)($ Mean \pm SD $)$ & Density $\left(\mathrm{N} / 1000 \mu \mathrm{m}^{3}\right)($ Mean \pm SD $)$ \\
\hline Mouse I\# & 13 & $69.2 \pm 23.5$ & $30.5 \pm 10.5$ & $2.28 \pm 0.25$ \\
\hline $2 \#$ & 15 & $105.3 \pm 32.3$ & $52.7 \pm 18.5$ & $2.03 \pm 0.16$ \\
\hline $3 \#$ & 13 & $79.8 \pm 35.4$ & $41.3 \pm 19.8$ & $1.98 \pm 0.26$ \\
\hline Sum & $4 I$ & $85.8 \pm 33.9$ & $42.0 \pm 18.9$ & $2.10 \pm 0.26$ \\
\hline Rat I\# & 10 & $59.1 \pm 16.5$ & $34.9 \pm 12.2$ & $1.78 \pm 0.38$ \\
\hline $2^{\#}$ & 15 & $70.1 \pm 16.9$ & $66.5 \pm 19.2$ & $1.10 \pm 0.26$ \\
\hline $3 \#$ & 17 & $72.4 \pm 24.8$ & $79.5 \pm 38.8$ & $0.98 \pm 0.26$ \\
\hline Sum & 42 & $68.4 \pm 20.7^{*}$ & $64.2 \pm 32.5^{*}$ & $1.20 \pm 0.42 *$ \\
\hline
\end{tabular}

$*_{t-T e s t, ~}<<0.05$, showing significant difference compared with the results of mice. $T B=$ Taste Bud. 
express synaptobrevin-2 [14]. In rat circumvallate taste buds, a large subset of synaptobrevin-2-LIR cells (73\%) also express $\mathrm{IP}_{3} \mathrm{R} 3$ [14]. Most all $\mathrm{IP}_{3} \mathrm{R} 3$ immunoreactive cells have been shown to be type II cells [21]. In the present study we have found that a greater percentage of rat taste cells display immunoreactivity for synaptobrevin2 versus the mouse (31.2\% vs $26.3 \%$ ). Likewise, rats have a larger percentage of taste cells expressing $\alpha$-gustducin and PLC $\beta 2$. These findings suggest that proportionally there are more type II cells in rat circumvallate papillae taste buds when compared with mouse. Although type II taste cells lack classical synapses, we do find that the type II taste cells contain some vesicles in the cytoplasm. The function of synaptobrevin-2 in type II taste cells is unclear, however, it suggests that synaptobrevin-2 may play a role in vesicle protein transportation, perhaps in the Golgi apparatus.

Several investigators have used different immunohistochemical methods to quantify taste cells displaying $\alpha$ gustducin or PGP 9.5 in rodent animals. Ueda et al. [25] used the avidin-biotin-horseradish peroxidase (ABC) method and concluded that approximately $24.2 \%$ of rat circumvallate papillae taste bud cells display $\alpha$-gustducinLIR and 14.6\% display PGP 9.5-LIR. The results in that study were based on 320 taste cells in 20 taste buds. This contrasts with our results from the rat ( $\alpha$-gustducin, $18 \%$; PGP 9.5, 9.4\%). This disparity may be due to: 1) The number of taste buds we sampled ( $\alpha$-gustducin: 197 taste buds; PGP 9.5: 144 taste buds in the present study versus approximately 20 taste buds by Ueda et al. [25]); 2) Our use of unbiased sampling; 3) Specimen preparation techniques, e.g., the use of different fixatives; 4) Immunocytochemical imaging methods e.g., ABC method vs immunofluorescence. Smith et al. [50] reported that rat circumvallate taste buds have a mean of $8.37 \alpha$-gustducinLIR cells per taste bud. Takeda et al. [26] found $\alpha$-gustducin-LIR in 33\% and PGP 9.5-LIR in 23\% of mouse circumvallate taste bud cells. We account for the difference in our results for the following reasons: 1) We used unbiased systematic sampling in our study; 2) We analyzed over 140 taste buds for each antibody; 3) In our study, taste cells were counted as immunoreactive only when a nuclear profile was present; 4) We counted immunoreactive taste cells using transverse sections versus longitudinal sections. In the transverse sections, there is no overlapping in taste cells, the immunoreactive taste cell profiles are obvious, and nuclei are easier to count. Takeda et al. [26] used polyclonal PGP 9.5 antibody in their study while we used a monoclonal PGP 9.5 antibody. However, our experience with polyclonal PGP 9.5 (Code No. 78630507, Biogenesis) is that it completely colocalizes in taste cells and nerve processes with monoclonal PGP 9.5 antibody (Code No. 7863-1004, Biogenesis). Finally, we conclude that a higher percentage of rat taste cells express $\alpha$ - gustducin $(18 \%)$ than in the mouse (14.6\%); while a smaller percentage of rat taste cells express PGP 9.5 $(9.4 \%)$ versus the mouse $(14.3 \%)$.

\section{Numerical density and size of taste buds}

It is generally accepted that a rodent taste bud contains 50 - 150 taste cells. We were curious to determine if there are differences in the numbers of cells in circumvallate taste buds between the rat and mouse. Our results clearly demonstrate that mouse taste buds are smaller in volume, but contain a larger number of smaller taste cells when compared with rat.

\section{Conclusion}

We have provided evidence that the rat and mouse differ in the percentages of taste cells expressing each of five taste signaling molecules: serotonin, PGP 9.5, $\alpha$-gustducin, PLC $\beta 2$ and synaptobrevin-2. These results, taken together with the differences taste cell size and numbers, suggest that rats and mice may possess different sensitivities to gustatory stimuli.

\section{Methods}

Adult Sprague-Dawley male rats (250-350 g, 45 days) and CF-1 male mice (25-30 g, 49 days) purchased from Charles River were used for these studies. Animals were cared for and housed in facilities approved by the Institutional Animal Care and Use Committee of the University of Denver. For studies involving serotonin, animals were injected with 5-hydroxytryptophan (5-HTP, $80 \mathrm{mg} / \mathrm{kg}$, i.p.) one hour before sacrifice. All animals were anesthetized with ketamine HCI about $270 \mathrm{mg} / \mathrm{kg}$ body weight for rats and $370 \mathrm{mg} / \mathrm{kg}$ body weight (i.p.) for mice. Animals were perfused for 10 seconds through the left ventricle with $0.1 \%$ sodium nitrite, $0.9 \%$ sodium chloride and 100 units sodium heparin in $100 \mathrm{ml} 0.1 \mathrm{M}$ phosphate buffer (pH 7.3). This was followed by perfusion with $4 \%$ paraformaldehyde in $0.1 \mathrm{M}$ phosphate buffer for $10 \mathrm{~min}$ utes [51]. All perfusates were warmed to $42^{\circ} \mathrm{C}$ before use. After perfusion the excised circumvallate papillae were fixed in fresh fixative for 3 hours at $4{ }^{\circ} \mathrm{C}$. The tissues were cryoprotected with $30 \%$ sucrose in $0.1 \mathrm{M}$ phosphate buffer overnight at $4^{\circ} \mathrm{C}$.

\section{Unbiased systematic sampling method}

Five adult Sprague-Dawley male rats and ten CF-1 male mice were perfused as for immunohistochemistry. Serial transverse sections ( $20 \mu \mathrm{m}$ thickness) were cut from the tissues containing circumvallate taste buds using a cryostat (HM 505E, MICRON, Laborgeräte GmbH, Germany). In order to obtain a systematic sample without bias throughout the papilla, each papilla was exhaustively sectioned. The serial sections were placed sequentially into individual wells in a 36-well culture dish. Every fifth section was saved starting with section $1,2,3,4$, or 5 . The 
beginning section number was determined using a new random number for each rat (e.g., sections 3, 8, 13, 18, and 23). Assuming that a taste bud is $80-100 \mu \mathrm{m}$ in length, sampling every fifth section will assure that no two sections will be from the same taste bud. Each group of sections contains 25-30 sections from five rat circumvallate papillae. For the sections from the mouse circumvallate papilla, every third section was saved using the sampling method described above.

\section{Immunofluorescence and nuclear staining}

Cryostat sections were blocked in 5\% normal goat serum and $0.3 \%$ Triton $\mathrm{X}-100$ in $0.1 \mathrm{M}$ phosphate buffered saline (PBS) ( $\mathrm{pH} 7.3$ ) for one hour at room temperature, followed by incubation in a primary antibody (Table 3 ) in $0.1 \mathrm{M}$ PBS ( $\mathrm{pH} 7.3$ ) overnight at $4^{\circ} \mathrm{C}$. After washing, the sections were exposed to affinity-purified secondary antibody Cy5 conjugated to goat anti-rabbit IgG (diluted to 1:200, cat no. 111-175-144, Jackson Lab) in 0.1 M PBS (pH 7.3) for one hour at room temperature. In order to image the nuclei the sections were stained using Sytox green nucleic acid stain (S-7020, Molecular Probes, Eugene, OR)

\section{Controls}

Primary antibodies were excluded from the processing to check for cross-reactivity. No immunoreactivity was observed under these conditions.

\section{Quantification of immunoreactive taste cells}

Confocal images were collected using a Zeiss Axioplan II with an Apotome attachment (Carl Zeiss Advanced Imaging Microscopy, Germany). Approximately 140-200 rat taste buds and 150-240 mouse taste buds per group were analyzed. Cells were scored as immunoreactive only if a nuclear profile was present in the cell. The total number of cells in the slice was determined by counting the number of Sytox stained nuclei for each taste bud. Finally, the percentage of immunoreactive taste cells was calculated by dividing the number of immunoreactive taste cells by the total number of the taste cells in each taste bud.

\section{Determination of numerical density of taste cells in rat and mouse taste buds}

After perfusion, the excised circumvallate papillae were fixed with fresh fixative for 3 hours at $4^{\circ} \mathrm{C}$. The tissues were then postfixed and stained for two hours in $1 \%$ osmium tetroxide $\left(\mathrm{OsO}_{4}\right)$ in $0.1 \mathrm{M} \mathrm{PO}_{4}$ buffer followed by a rinse in $0.05 \mathrm{M}$ sodium maleate buffer ( $\mathrm{pH}$ 5.2). The blocks were then stained en bloc in 1\% uranyl acetate in $0.025 \mathrm{M}$ sodium maleate buffer ( $\mathrm{pH}$ 6.0) overnight at $4{ }^{\circ} \mathrm{C}$, followed by dehydration and embedding in Eponate 12. The blocks were the re-embedded using the technique of Crowley and Kinnamon [52].

Serial thin sections $(1 \mu \mathrm{m})$ were cut with a Diatome HistoJumbo Knife using a Leica Ultracut UCT Ultramicrotome. Typically a ribbon of about 20 sections was collected onto a glass slide. After drying on a hot plate the sections were stained with toluidine blue for 5 minutes. Images of taste buds were recorded using a Zeiss Axioplan II with an Apotome attachment. The images of taste buds were collected from every other section. Using Adobe Photoshop we compared every two adjacent images and identified the number of newly occurring taste cell nuclei. The number of taste cells in a taste bud was the sum of newly occurring taste cell nuclei that appeared in every other image in the series.

The volume of a taste bud was calculated according to following formula: Volume $\left(\mu \mathrm{m}^{3}\right)=\Sigma_{1-n}\left(37.2 \times 2 \times \mathrm{C}_{\mathrm{n}}\right)(\mathrm{C}$ : number of crosses on taste bud image; $n$ : image number; 2: the thickness is $2 \mu \mathrm{m}$ between two adjacent images). We superimposed an image of grids $(20 \times 20$ grids, $1 \mathrm{~cm} /$ grid $)$ over the image of a taste bud profile and counted the number of crosses within a taste bud profile. Each cross represents an area of $37.2 \mu \mathrm{m}^{2}$. Every taste bud area was multiplied by the thickness between two adjacent sections and summed to determine the volume of the section. The volumes of all of the sections were summed to obtain the volume of the taste bud.

Numerical density of taste cells in a taste bud was calculated by dividing the number of taste cells by the volume of the taste bud.

Table 3: Primary antibodies

\begin{tabular}{llccc}
\hline \multicolumn{1}{c}{ Antibodies } & Species & Dilution & Source & Cat No. \\
\hline Serotonin & Rabbit & I:100 & ImmunoStar & 20080 \\
PGP 9.5 & Rabbit & $1: 200$ & Biogenesis & $7863-0507$ \\
$\alpha$-gustducin & Rabbit & I:200 & Santa Cruz & sc-395 \\
PLCB2, & Rabbit & I:200 & Santa Cruz & sc-206 \\
Synaptobrevin-2 & Rabbit & $1: 100$ & Wako & $018-15791$
\end{tabular}




\section{Statistical analysis}

Statistical analysis for the percentages of immunoreactive taste cells in Figure 2 and the numerical density of taste cells in Table 2 were performed using the Student $t$-test.

\section{Authors' contributions}

HM, RY, and JCK participated in the study design. HM carried out the animal experiments. The quantitation data were collected and analyzed by HM, RY, and ST. HM drafted the manuscript. The study was conceived and funded by JCK. All authors participated in the writing of and approved the final manuscript.

\section{Acknowledgements}

We would like to thank Ms. Lulu Yip for her excellent technical assistance and Mr. John M. Basgen for his technical expertise in unbiased sampling and quantitation. This study was supported by NIH grants DC00285 to JCK and NIH P30 Colorado Chemosensory Core Grant DC004657 (D. Restrepo, P.I.).

\section{References}

I. Farbman Al: Fine structure of the taste bud. J Ultrastruct Res 1965, I 2:328-350.

2. Murray RG: The ultrastructure of taste buds. In The ultrastructure of sensory organs Edited by: Friedemann I. Amsterdam: North Holland Pub Co; 1973:I-8I.

3. Takeda M, Hoshino $\mathrm{T}$ : Fine structure of taste buds in the rat. Arch Histol Jpn 1975, 37:395-4I3.

4. Kinnamon JC, Taylor BJ, Delay RJ, Roper SD: Ultrastructure of mouse vallate taste buds. I. Taste cells and their associated synapses. J Comp Neurol 1985, 235:48-60.

5. Kinnamon JC, Sherman TA, Roper SD: Ultrastructure of mouse vallate taste buds: III. Patterns of synaptic connectivity. J Comp Neurol 1988, 270: I- 10.

6. Kinnamon JC, Henzler DM, Royer SM: HVEM ultrastructural analysis of mouse fungiform taste buds, cell types, and associated synapses. Microsc Res Tech 1993, 26:142-156.

7. Royer SM, Kinnamon JC: Ultrastructure of mouse foliate taste buds: synaptic and nonsynaptic interactions between taste cells and nerve fibers. J Comp Neurol 1988, 270: I I-24.

8. Royer SM, Kinnamon JC: HVEM serial-section analysis of rabbit foliate taste buds: I. Type III cells and their synapses. J Comp Neurol 1991, 306:49-72.

9. Royer SM, Kinnamon JC: Application of serial sectioning and three dimensional reconstruction to the study of taste bud ultrastructure and organization. Micro Res Tech 1994, 29:38I-407.

10. Pumplin DW, Yu C, Smith DV: Light and dark cells of rat vallate taste buds are morphologically distinct cell types. J Comp Neurol 1997, 378:389-4I0.

II. Yee CL, Yang R, Böttger B, Finger TE, Kinnamon JC: "Type III" cells of rat taste buds: Immunohistochemical and ultrastructural studies of neuron-specific enolase, protein gene product 9.5, and serotonin. J Comp Neurol 200I, 440:97-I08.

12. Yee CL, Jones KR, Finger TE: Brain-derived neurotrophic factor is present in adult mouse taste cells with synapses. J Comp Neurol 2003, 459: I5-24.

13. Yang R, Crowley HH, Rock ME, Kinnamon JC: Taste bud cells with synapses express SNAP-25-like immunoreactivity. J Comp Neurol 2000, 424:205-2I5.

14. Yang R, Stoick CL, Kinnamon JC: Synaptobrevin-2-like immunoreactivity is associated with vesicle at synapses in rat circumvallate taste buds. J Comp Neurol 2004, 47 I:59-7I.

15. Murray RG, Murray A: Relation and possible significance of taste bud cells. Contrib Sens Physiol I 97I, 5:47-95.

16. Murray RG: The mammalian taste bud type III cells: a critical analysis. J ultrastruct Mol Struct Res 1996, 95(I-3): 175-188.

17. Lindemann B: Taste reception. Physiol Rev 1996, 76(3):718-766.
18. Lawton DM, Furness DN, Lindemann B, Hackney CM: localization of the glutamate-aspartate transporter, GLAST, in rat taste buds. Eur J Neurosci 2000, I2(9):3163-3I7I.

19. Yang R, Tabata S, Crowley HH, Margolskee RF, Kinnamon JC: Ultrastructural location of gustducin immunoreactivity in microvilli of type II taste cells in the rat. J Comp Neurol 2000, 425:|39-|5|.

20. Clapp TR, Stone LM, Margolskee RF, Kinnamon SC: Immunocytochemical evidence for co-expression of Type III IP ${ }_{3}$ receptor with signaling components of bitter taste transduction. $B M C$ Neurosci 200I, 2:6.

21. Clapp TR, Yang R, Stoick CL, Kinnamon SC, Kinnamon JC: Morphological characterization of rat taste receptor cells that express components of the phospholipase $\mathbf{C}$ signaling pathway. J Comp Neurol 2004, 468:3 I I-32 I.

22. Miyoshi MA, Abe K, Emori Y: IP(3) receptor type 3 and PLC $\beta 2$ are co-expressed with taste receptors $T I R$ and $T 2 R$ in rat taste bud cells. Chem Senses 200I, 26:259-265.

23. Kim D-J, Roper SD: Localization of serotonin in taste buds: $\mathbf{A}$ comparative study of four vertebrates. J Comp Neurol 1995, 353:364-370.

24. Nelson GM, Finger TE: Immunolocalization of different forms of neural cell adhesion molecule (NCAM) in rat taste buds. J Comp Neurol 1993, 336:507-516.

25. Ueda K, Fujii M, El-Sharaby A, Honma S, Wakisaka S: Human blood group antigen $\mathbf{H}$ is not the specific marker for type I cells in the taste buds. Arch Histol Cytol 2003, 66(5):469-473.

26. Takeda M, Suzuki Y, Obara N, Uchida N, Kawakoshi K: Expression of GDNF and GFR $\alpha$ I in mouse taste bud cells. J Comp Neurol 2004, 479:94-102.

27. Richter TA, Dvoryanchikov GA, Roper SD, Chaudhari N: Acid-sensing ion channel-2 is not necessary for sour taste in mice. J Neurosci 2004, 24:4088-4091.

28. Kinnamon SC, Price MP, Stone LM, Lin W, Welsh MJ: The acid sensing ion channel $\mathrm{BNCl}$ is not required for sour taste transduction. Internal Symp Olfact Taste 2000, I 3:80.

29. Zaidi FN, Whitehead MC: Discrete innervation of murine taste buds by peripheral taste neurons. J Neurosci 2006, 26:8243-53.

30. Whitehead MC, Ganchrow JR, Ganchrow D, Yao B: Organization of geniculate and trigeminal ganglion cells innervating single fungiform taste papillae: a study with tetramethylrhodamine dextranamine labeling. Neurosci 93:931-941.

31. Wong GT, Gannon KS, Margolskee RF: Transduction of bitter and sweet taste by gustducin. Nature 1996, 38 I(6585):737-738.

32. Kinnamon SC: Taste transduction. A bitter-sweet beginning. Nature 1996, 38 I(6585):737-8.

33. Kinnamon SC, Margolskee RF: Mechanisms of taste transduction. Curr Opin Neurobiol 1996, 6(4):506-13.

34. Margolskee RF: Molecular mechanisms of taste transduction. Pure Appl Chem 2002, 74(7): I I25-I I33.

35. Ruiz CJ, Wray K, Delay E, Margolskee RF, Kinnamon SC: Behavioral evidence for a role of alpha-gustducin in glutamate taste. Chem Senses 2003, 28(7):573-9.

36. He W, Yasumatsu K, Varadarajan V, Yamada A, Lem J, Ninomiya $Y$, Margolskee RF, Huang YJ, Maruyama Y, Lu KS, Pereira E, Plonsky I, Baur JE, Wu D, Roper SD: Mouse taste buds use serotonin as a neurotransmitter. J Neurosci 2005, 25(4):843-7.

37. Zhang $Y$, Hoon MA, Chandrashekar J, Mueller KL, Cook B, Wu D, Zuker CS, Ryba NJP: Coding of sweet, bitter, and umami tastes: different receptor cells sharing similar signaling pathways. Cell 2003, I I 2:293-30I.

38. Schiavo G, Benfenati F, Poulain B, Rossetto O, Polverino de Laureto $P$, Dasgupta BR, Montecucco C: Tetanus and botulinum-B neurotoxins block neurotransmitter release by proteolytic cleavage of synaptobrevin. Nature 1992, 359(6398):832-5.

39. Südhof TC: The synaptic vesicle cycle. Annu Rew Neurosci 2004, 27:509-47.

40. Deak F, Schoch S, Liu X, Südhof TC, Kavalali ET: Synaptobrevin is essential for fast synaptic-vesicle endocytosis. Nat Cell Biol 2004, 6( I I): I I02-8.

4I. Namik K, Shen T, Lu S, Zhao F, Herness S: A paracrine signaling role for serotonin in rat taste buds: expression and localization of serotonin receptor subtypes. Am J Physiol Regul Inter Comp Physiol 2004, 286:R649-658. 
42. Huang YJ, Maruyama Y, Lu KS, Pereira E, Plonsky I, Baur JE, Wu D, Roper SD: Mouse taste buds use serotonin as a neurotransmitter. J Neurosci 2005, 25(4):843-7.

43. Fujimoto $\mathrm{S}$, Ueda $\mathrm{H}$, Kagawa $\mathrm{H}$ : Immunocytochemistry on the localization of 5-hydroxytryptamine in monkey and rabbit taste buds. Acta Anat (Basel) 1987, 1 28:80-83.

44. Uchida T: Serotonin-like immunoreactivity in the taste bud of the mouse circumvallate papilla. Jpn J Oral Biol 1985, 27:132-139.

45. Bourne J, Kinnamon JC: Co-localization of serotonin-like immunoreactivity with synaptic proteins in taste buds of rat. Chem Senses 1999, 24:589.

46. Doran JE, Jackson P, Kenoch PA, Thompson RJ: Isolation of PGP 9.5, a new human neuron-specific protein detected by highresolution two-dimensional electrophoresis. I Neurochem 1983, 40(6): 1542-7.

47. Thompson RJ, doran JF, Jackson P, Dhillon AP, Rode J: PGP 9.5 - a new marker for vertebrate neurons and neuroendocrine cells. Brain Res 1983, 278(I-2):224-8.

48. Iwanaga $\mathrm{T}$, Han $\mathrm{H}$, Kanazawa $\mathrm{H}$, Fujita $\mathrm{T}$ : Immunohistochemistry localization of protein gene product 9.5 (PGP 9.5) in sensory paraneurons of rat. Biomed Res 1992, 13:225-230.

49. Kanazawa $\mathrm{H}$, Yoshie $\mathrm{S}$ : The taste bud and its innervation in the rat as studied by immunohistochemistry for PGP 9.5. Arch Histol Cytol 1996, 59(4):357-367.

50. Smith DV, Som J, Boughter JD Jr, ST John SJ, Yu C, Christy RC: Cellular expression of $\alpha$-gustducin and the $A$ blood group antigen in rat fungiform taste buds cross-reinnervated by the IXth nerve. J Comp Neurol 1999, 409: I I8-130.

5I. Weedman DL, Pongstaporn T, Ryugo DK: Ultrastructural study of the granule cell domain of the cochlear nucleus in rats: mossy fiber endings and their targets. J Comp Neurol 1996, 369:345-360.

52. Crowley $\mathrm{HH}$, Kinnamon JC: Transmission electron microscopy of gustatory epithelium. In Experimental cell biology of taste and olfaction: current techniques and protocols Edited by: Spielman Al, Brand JG. Boca Raton, FL: CRC Press; 1995:105-I I4.

Publish with Bio Med Central and every scientist can read your work free of charge

"BioMed Central will be the most significant development for disseminating the results of biomedical research in our lifetime. "

Sir Paul Nurse, Cancer Research UK

Your research papers will be:

- available free of charge to the entire biomedical community

- peer reviewed and published immediately upon acceptance

- cited in PubMed and archived on PubMed Central

- yours - you keep the copyright

Submit your manuscript here:

http://www.biomedcentral.com/info/publishing_adv.asp
BiolMedcentral 